\title{
Time resolved sulphur and nutrient distribution in Norway spruce drill cores using ICP-OES
}

\author{
Andrea Ulrich • Timothée Barrelet • Renato Figi • \\ Heinz Rennenberg • Urs Krähenbühl
}

Received: 8 May 2008 / Accepted: 26 August 2008 / Published online: 23 September 2008

(C) Springer-Verlag 2008

\begin{abstract}
Methods were developed for detailed dendrochemical studies of low sulphur contents in Norway spruce (Picea abies L. Karst.). This tree species is the dominant conifer species in Northern and Central Europe and therefore predestined for a possible use as an environmental archive. Two independent digestion procedures were investigated with respect to their suitability for element determination and optimised for analysis of the low sulphur content in wood. A modified oxygen bomb combustion
\end{abstract}

Electronic supplementary material The online version of this article (doi:10.1007/s00604-008-0101-7) contains supplementary material, which is available to authorized users.

\footnotetext{
A. Ulrich $(\bowtie) \cdot$ T. Barrelet $\cdot$ R. Figi

Analytical Chemistry, Swiss Federal Institute for Materials

Science and Technology (EMPA),

Überlandstrasse 129,

8600 Dübendorf, Switzerland

e-mail: andrea.ulrich@empa.ch

T. Barrelet

e-mail: timothee.barrelet@bag.admin.ch

T. Barrelet

Swiss Federal Office of Public Health (FOPH),

3003 Berne, Switzerland

H. Rennenberg

Institute of Forest Botany and Tree Physiology,

University of Freiburg,

Georges-Köhler-Allee 53,

79085 Freiburg, Breisgau, Germany

e-mail: heinz.rennenberg@ctp.uni-freiburg.de

T. Barrelet • U. Krähenbühl

Department for Chemistry and Biochemistry, University of Berne,

Freiestrasse 3,

3012 Berne, Switzerland

U. Krähenbühl

e-mail: urs.kraehenbuehl@iac.unibe.ch
}

procedure and a microwave acid digestion procedure were evaluated with the goal to obtain sufficient detection limits in order to access low concentrated non-metals with an appropriate time resolution. Method development included evaluation of strategies preventing losses of volatile sulphur species. Digestion efficiency was demonstrated by recovery rates for various certified plant standard reference materials (NIST 1572, NIST 1547, RM 8436, BCR 101, NIST 1515, RM 8436, NIST 1573, NIST 1575) as well as self prepared standards with defined low sulphur content of 20 to $200 \mathrm{mg} \mathrm{kg}^{-1}$, which are typical for Norway spruce wood samples. Ultra sonic nebulisation (USN) was evaluated with respect to signal enhancement for sample introduction to inductively coupled plasma optical emission spectrometry (ICP-OES). The optimised procedure was applied to Norway spruce drill cores from locations with different environmental conditions in Switzerland, in order to investigate the anthropogenic impact of sulphur and the suitability of Norway spruce as an environmental archive for sulphur.

Keywords Norway spruce · Tree ring · Sulphur . Trace elements · Oxygen bomb combustion · Microwave digestion $\cdot$ ICP-OES $\cdot$ Plant certified reference material

\section{Introduction}

The goal of this study was to investigate whether trees are appropriate environmental archives for sulphur. They are among the most popular archives because they are widespread and can be found in remote areas as well as in cities, close to anthropogenic pollution sources. Furthermore, sampling using increment borers is relatively easy and risk of sample losses or deterioration is low. Additionally, tree rings make dating very precise. In conifers particularly, 
individual tree rings can be distinguished easily. Conifers can be found in most parts of the globe. In the northern hemisphere, the genus Picea is very common, which was one of the main reasons why Picea abies (Norway spruce) was selected for this study.

Environmental archive investigations using tree drill cores are particularly demanding with respect to time resolution. This is because sulphur content in Norway spruce wood is low and ranges between 20 and $200 \mathrm{mg} \mathrm{kg}^{-1}$. Hence, a sample preparation method appropriate for determination of low contents is required. Several digestion methods were proposed for the determination of metals in wood, but none was found to be appropriate for the analysis of low sulphur content with adequate time resolution and low detection limits.

In several studies, digestions of 5 to 10 year drill core segments were performed for the determination of metals. Open acid digestions had been applied in applications from the 1990ies [1-3] whereas microwave acid digestion in closed PTFE (polytetrafluoroethylene) pressure bombs is commonly used today for the decomposition of environmental or biological samples [4-7]. Most of the digestions methods were optimised for the determination of trace metals, using different acid mixtures such as mixtures of $\mathrm{HNO}_{3}$ and $\mathrm{HClO}_{4}[2,3,8], \mathrm{HNO}_{3}, \mathrm{H}_{2} \mathrm{O}_{2}$ and $\mathrm{HF}[5,6]$ or $\mathrm{HNO}_{3}$ and $\mathrm{H}_{2} \mathrm{O}_{2}$. [4, 9]. Digestion methods for sulphur determination in other plant materials were developed by Randal and Spencer, who described an open digestion procedure using $\mathrm{HNO}_{3}$ and $\mathrm{HClO}_{4}$ [3]. Zhao et al. [10] compared three digestion procedures with $\mathrm{HNO}_{3}-\mathrm{HClO}_{4}$ mixture, fuming $\mathrm{HNO}_{3}-\mathrm{KNO}_{3}$ and an alkaline $\mathrm{NaOBr}$ decomposition method. Other authors applied microwave digestion procedures in dendrochemical investigations of metals. A mixture of $\mathrm{HNO}_{3}, \mathrm{HCl}$ and $\mathrm{HF}$ was proposed for bark [7], but the addition of $\mathrm{HCl}$ and $\mathrm{HF}$ is not compulsory for the digestion of wood. Digestion of wood in $50 \% \mathrm{H}_{2} \mathrm{O}_{2}$ was also described [11].

One study recommended a mixture of $\mathrm{HNO}_{3}$ and $\mathrm{HClO}_{4}$ in quartz cups [12]. However, a digestion with perchloric acid is usually not necessary for the digestion of wood tissue. With respect to sulphur analysis, the use of $\mathrm{HClO}_{4}$ is disadvantageous because of the high sulphur contamination levels in commercially available $\mathrm{HClO}_{4}$. Even in ultra pure purity grade acid the contamination of $\mathrm{HClO}_{4}$ is higher than $5 \mathrm{mg} \mathrm{L}{ }^{-1} \mathrm{SO}_{4}{ }^{2-}$ in $\mathrm{HClO}_{4} 70 \%$ Merck Suprapur ${ }^{\circledR}$ in contrast to maximum $200 \mu \mathrm{g} \mathrm{L}^{-1} \mathrm{SO}_{4}{ }^{2-}$ in $\mathrm{HNO}_{3} 65 \%$ Merck Suprapur ${ }^{\circledR}$.

Digestion of wood powder by heating in $\mathrm{HNO}_{3}$ on a heating block [13] was proposed for metal determination but is inadequate for sulphur due to losses of volatile compounds. Ashing of wood samples and subsequent digestion with $\mathrm{HNO}_{3}$ as described by Gaoming [14] has the major disadvantage of relatively high sample quantities being required. Hence, the method provides a relatively low time resolution of 10 years only. Moreover, the procedure is time consuming and losses of volatile sulphur components during the ashing procedure are likely, hence restricting the detection limit.

With the exception of the Gaoming procedure, all above mentioned studies were focussed on the determination of metals. Moreover, all authors mentioned above used sample amounts between 200 and $500 \mathrm{mg}$ for the decomposition, which was relatively high compared to the tree increments used for this study which weighted between 50 and $200 \mathrm{mg}$ only.

Since none of the procedures mentioned above was deemed appropriate to fulfil the purpose, a suitable digestion method had to be developed for the determination of low non-metal contents such as sulphur or phosphorus and for the multi-elemental determination of metals in tree ring analysis. Therefore, two independent decomposition procedures were developed, optimised and applied for analysis of low sulphur content in wood samples. Moreover, the suitability of the method had to be evaluated for the determination of metals and phosphorus in wood samples. The methods were validated using standard reference materials and self-made standards with low sulphur contents.

\section{Experimental}

\section{Samples}

\section{Tree sampling and site description}

Picea abies L. Karst (Norway spruce) was chosen for the present study. In Switzerland, it represents $48 \%$ of all trees and also grows in high altitudes. Three forests were selected: two in the Swiss Plateau (Düdingen, $580 \mathrm{~m}$ above sea level, Frieswil, $740 \mathrm{~m}$ above sea level), and one at the alpine site of St Moritz (Engadine, 1,900 $\mathrm{m}$ above sea level). The $\mathrm{SO}_{2}$ emission situation is different for each sampling site and is lowest at the alpine location St Moritz. In Düdigen and St. Moritz, peat bogs can be used for comparison as independent environmental archive. The peat bog at the Alpine sampling site St. Moritz is located about $100 \mathrm{~m}$ underneath the sampled forest. Düdingen has the highest pollution levels due to the proximity of the forest to the motorway A12 (Berne-Fribourg), which is about $500 \mathrm{~m}$ away from the forest. The Düdingen peat bog is near the forest, about $1 \mathrm{~km}$ away. In Frieswil, a rural site without direct $\mathrm{SO}_{2}$ source, atmospheric concentrations of the pollutant are at an intermediate level.

At all sampling sites, mature forest trees were selected. The circumference of each tree was determined before sampling. Trees of different size were sampled in order to assess possible 
ageing effects. Drill cores were taken at breast height using a 5 $\mathrm{mm}$ increment borer (Suunto, www.suunto.com). The contamination levels of potential cleansing agents for the corer were determined before the sampling campaign in order to ensure that the both corer and metal tongue were devoid of sulphur. Measurements using ICP-OES revealed that WD40 ${ }^{\circledR}$, which contains $21 \%$ mineral oil, was not suitable because it is rich in sulphur. PhEur grade paraffin (Hänseler, www.haenseler.ch) was finally chosen for cleaning and lubricating the sampling tools because of its low background contamination. It was found to contain only traces of sulphur which were below detection limit of $10 \mathrm{mg} \mathrm{kg}^{-1}$ for XRF (x-ray fluorescence spectrometry). Gloves were used in order to avoid contamination during coring and sample preparation. For comparison of different analysis methods, six drill cores per tree were taken in four directions. Two of them were used for radiodensitometry, two for LASER ablation high resolution ICP magnetic sector field mass spectrometry, one for $\mathrm{x}$-ray absorption spectroscopy, and the remaining one for the digestion and combustion procedures developed within this study. The extent of the sapwood zone of each drill core was determined immediately after sampling, since for Norway spruce wood no visual differentiation between sapwood and heartwood is possible after drying. For interpretation of element profiles in a tree, determination of the sapwoodheartwood boundary is important. The samples were then pressed into weighted and previously cleaned PVC (polyvinyl chloride) rails, and wrapped in a polyvinylidene chloride foil (Saran). Afterwards, they were kept in the rails and dried at $40^{\circ} \mathrm{C}$ until weight constancy. Water content of the wood was determined as weight loss after drying.

\section{Reagents and chemicals}

Only ultra pure quality acids (Merck, www.merck.de) and high-purity water $\left(18.2 \mathrm{M} \Omega \mathrm{cm}^{-1}\right.$, prepared by a Milli-Q Gradient A10 System, Millipore, www.millipore.com) were used for sample and standard preparation. Standards were prepared from single and multi-element standards of ICPquality (Merck and Alfa Aesar). Cleaning and sample digestions were also performed using acids of Suprapur ${ }^{\circledR}$ quality (Merck) and high-purity water. Cellulose powder (20 $\mu$, Aldrich) was used for fabrication of doped cellulose standards used for validation of the acid microwave digestion procedure. Spiked wood samples were prepared from pulverised wood briquettes with an average sulphur content of $58 \pm 4.6 \mu \mathrm{g} \mathrm{g}^{-1}$

\section{Sample preparation}

Two sample preparation procedures were investigated for optimum sample decomposition of wood samples. These procedures had to allow precise determination for metals on one hand and accurate quantification of sulphur and phosphorus in low contents on the other hand. A further goal was the optimisation by minimising sample amounts in order to achieve best time resolution for tree ring investigations. Both acid digestion using microwave and a modified oxygen bomb combustion procedure, originally developed for sulphur and halogen determination in oil or coal, were investigated and optimised $[15,16]$.

\section{ICP-OES analysis}

All analyses were performed by inductively coupled plasma optical emission spectrometry using either a sequential Varian Liberty 150 AX Turbo with axial torch or a simultaneous Varian VistaPro (www.varianinc.com) with a radial torch. For sulphur determination on the Varian Liberty 150 AX Turbo, the optical chamber had to be rinsed with nitrogen because oxygen absorbs the sulphur emission line. On the Varian VistaPro, the optical chamber was rinsed with Ar. Both instruments were operated under standard hot plasma conditions.

For analysis of the alkaline solutions obtained by oxygen bomb combustion, a Varian HF kit had to be mounted because of the quartz-damaging alkaline solutions (about $0.4 \mathrm{M} \mathrm{NaOH}$ ). The kit consists of a PEEK (polyetheretherketone) V-groove nebulizer, a PTFE spray chamber and a demountable quartz torch with corundum injector tube.

The microwave acid digestions were analysed using a standard quartz sample introduction system consisting of a Meinhard nebulizer and a Twister cyclonic spray chamber for the VistaPro. For the Liberty 150 AX Turbo a Cetac ultrasonic nebulizer AT5000+ (USN) was available. The USN was used to improve the signal intensity particularly for elements with low concentrations such as sulphur and phosphorus. The signal enhancement factor of the USN in comparison to the Meinhard nebulizer was about 7 for sulphur and about 13 for phosphorus, which corresponds to the findings of Wennrich et al. [9] who found enhancement factors of 4.9 for sulphur and 4.3 for phosphorus for a Spectroflame ICP-OES (Spectro Analytical Instruments).

\section{Radiodensitometry}

For dating and assessment of abrupt growth changes or reaction wood, two supplementary drill cores were taken from the trees and measured by radiodensitometry. Wood density and tree ring width of the additional drill cores were measured at the installations of the Swiss Federal Institute for Forest, Snow and Landscape Research, Birmensdorf (WSL, www.wsl.ch). For this purpose, $1.2 \mathrm{~mm}$ thick splinters were sawn out of the fixed core, at right angle to the direction of fibre. After conditioning $\left(20^{\circ} \mathrm{C}, 50 \%\right.$ relative air humidity), the wood samples were $\mathrm{x}$-rayed. 
Optical density of the negatives obtained was measured with a Dendro 2003 microdensitometer (Walesch Electronic, www.walesch.ch). The optical density corresponds to the volumetric-gravimetric wood density. In this article, this information was used for exact dating of the drill cores. Further details can be found in [17-19].

\section{Results and discussion}

Development of the oxygen bomb combustion

The oxygen bomb combustion was chosen for independent comparison with the acid microwave digestion. The oxygen bomb combustion procedure is routinely used for determining the halogen and sulphur content in coal and petroleum products [20]. The digestion procedure is well validated for this application and comprises all relevant sulphur components including the volatiles. However, it was never applied to wood samples before. This type of material is particularly challenging because of its low sulphur content of only about $50 \mathrm{mg}$ per $\mathrm{kg}$ in average, which means about 60 times lower values than the sulphur content in coal.

Combustion of the wood samples with oxygen was performed in a sealed decomposition vessel with catalytic coating. All sulphur compounds contained in the wood were converted to sulphate during the rapid combustion. The oxygen pressure bomb combustion was performed using an Ika AOD 1 system and following the DIN 51577 procedure (www.din.de). Using a carefully cleaned scalpel, the drill cores were cut into segments comprising ten tree rings each. A minimum of $70 \mathrm{mg}$ wood sample were put into a quartz crucible, which was then placed into a holder. A cotton thread leading to the crucible was fixed to the ignition wire, and both sample and thread were moistened with about $1 \mathrm{ml}$ ethanol p.a. for combustion support. Ten millilitres $1 \mathrm{M} \mathrm{NaOH}$ (p.a. grade) were dosed into decomposition vessel for absorption of the combustion gasses. Previous optimisation studies showed that no $\mathrm{H}_{2} \mathrm{O}_{2}$ is required for additional oxidation. The cover/crucible holder was then screwed onto the decomposition vessel. After filling the apparatus with oxygen (5.0 quality) up to 30 bar inner pressure $(6 \mathrm{~L})$, the combustion was started by ignition. Subsequently, the oxygen bomb was placed into a water bath for cooling and nodded in order to allow contact of the whole inner part with the absorption liquid. Ten minutes later, the apparatus was vented. Previous controls demonstrated that venting does not require the connection to a gas washing flask with supplementary absorption liquid. Before each new measurement, decomposition vessel and crucible holder were rinsed with ultra-pure water and dried. Combustions were all exempt of residue, except of a small amount of sooth in the glass crucible, which was wiped away with a towel. The presence of soot is tantamount to an incomplete combustion of the carbon fraction in wood, but does not signify incomplete sulphur oxidation. The use of one-way cellulose acetobutyrate crucibles was found to be unsuitable because they increased the blank value 2.6 times compared to quartz glass crucibles.

The combustion procedure was optimised and validated using sulphate solutions $\left(1 \mathrm{mg} \mathrm{\textrm {L } ^ { - 1 }}\right)$, and standard reference materials (BCR 101, powdered spruce needles, $1,700 \pm 40 \mu \mathrm{g} \mathrm{g}^{-1} \mathrm{~S}$ ). The recovery rates for synthetic sulphur samples ranged at about $97 \%$. For BCR 101, recovery rates up to $90 \%$ of the certified value were obtained, but in average the recovery rates were only about $80 \%$. The optimisation of the reagent types and volumes showed that a careful optimisation of the $\mathrm{NaOH}$ concentration in the absorption liquid is important in terms of recovery rates. The concentration was finally optimised to $1 \mathrm{M} \mathrm{NaOH}$. Lower concentration resulted in much lower recovery rates. The findings point to a systematic error in the present digestion procedure.

The oxygen bomb combustion method was also applied to real wood samples. One tree per sampling site was selected. For tree samples, a compromise had to be made between minimal weight of the sample and best obtainable time resolution. Drill cores with a diameter of $5 \mathrm{~mm}$ had to be cut in 10 year segments in order to reach the required minimum sample weight of $70 \mathrm{mg}$. Due to the low sulphur content in wood, a sufficient sulphur level was only measured for one out of three drill cores. The only drill core providing enough sulphur content originated from a St Moritz tree. The sulphur contents in the drill cores from the Swiss Plateau trees displayed only values below detection limit. The use of a $12 \mathrm{~mm}$ drill core might solve the problem. Another possibility might be minimisation of the combustion devices including vessel volume.

However, it appears that oxygen bomb combustion was not an optimal choice for the determination of sulphur in wood. The present procedure does not provide reliable results for the sulphur content of wood samples. Moreover, the detection limits were relatively poor and the required sample amounts were relatively high. An adequate minimisation of the required sample amount is challenging: the detection limits achievable so far for decomposition procedure of small sample amounts of 70 and $200 \mathrm{mg}$ are not adequate for low sulphur contents in wood tissue.

The reagents might be a significant contamination sources since neither $\mathrm{NaOH}$ nor ethanol were available in high purity quality. Decomposition vessels could be an additional contamination source. However, further optimisations were discarded since minimisation of the required sample amount is limited in the present composition system and the procedure is complex and time consuming. Better 
results were obtained by the microwave acid digestion described below.

\section{Development of a microwave acid digestion}

The main goal of the development of this digestion procedure was to achieve a good temporal resolution and a reliable quantification of the total sulphur content with good recovery rates. Thus, the decomposition procedure was carefully optimised with respect to accurate quantification of very small amounts of sulphur in Norway spruce wood. It contains only an average of $5 \mu \mathrm{g} \mathrm{S}$ per $100 \mathrm{mg}$ drill core piece. Therefore, digestion was optimised with special attention to minimum sample weight, optimum acid mixture, minimised sample losses and contamination risk.

Using a clean scalpel, the drill cores were cut into fiveten tree ring segments, depending on the weight. A minimum sample weight of about $40 \mathrm{mg}$ was required to ensure accuracy. A 1:1 mixture $(2 \times 2.5 \mathrm{ml})$ of nitric acid $\mathrm{HNO}_{3} 65 \%$ and hydrogen peroxide $\mathrm{H}_{2} \mathrm{O}_{2}, 30 \%$ (both Merck Suprapur ${ }^{\circledR}$, www.merck.de) was finally selected for the microwave digestion. All digestions were performed in a MLS ETHOS 1600 microwave oven controlled by software version easyWAVE3 or in a MLS ETHOS 1200 microwave (MLS Milestone, www.milestonesci.com). Table S1 (available online in the supplementary information) shows the digestion program finally used. The maximal pressure was set at 25 bar for the pressure and temperature controlled MLS Ethos 1600 system, whereas the MLS Ethos 1200 system is only temperature and power controlled.

Hafez et al. [2] recommended an addition of $\mathrm{MgO}$ in open digestions of biological samples with high methionine concentrations to improve the sulphur recovery rates using ion chromatography determination. Jeker and Krähenbühl [21] also recommended an addition of $\mathrm{MgO}$ for the microwave acid digestions of material from peat bogs with the aim to avoid sulphur losses by the formation of $\mathrm{MgSO}_{4}$. In order to verify if an addition of $\mathrm{MgO}$ is preferable for wood samples as well, several digestions in pure acid and with addition of increasing amounts of $\mathrm{MgO}(0,22.5,45$, 90 and $135 \mathrm{mg} \mathrm{L}^{-1}$ ) were performed using the BCR-CRM 101 (Pine Needles), as well as homogenised wood powder (background $\mathrm{S}$ content of $58 \pm 4.6 \mu \mathrm{g} \mathrm{g}^{-1}$ ). Furthermore, homogenised wood powder doped with $20 \mu \mathrm{g} \mathrm{g}^{-1}$ sulphate and others doped with $20 \mu \mathrm{g} \mathrm{g}^{-1}$ cysteine were decomposed in presence of different concentrations of $\mathrm{MgO}$. The results of the doped wood standards showed no remarkable influence of the $\mathrm{MgO}$ on the recovery rate (Figure $\mathrm{S} 1$ in the online available supplementary information). Thus, natural magnesium content in wood samples seems to be high enough to fulfil this function. The natural $\mathrm{Mg}$ content in Norway spruce varies between 100 and $560 \mathrm{mg} \mathrm{kg}^{-1}$ [22]. Also for the certified reference material BCR 101, an addition of $\mathrm{MgO}$ did not result in significant changes or improved recovery rates. Therefore, addition of $\mathrm{MgO}$ was deemed unnecessary for digestion of sulphur in wood samples. The amount of magnesium in Norway spruce wood is about six times superior to that of sulphur and therefore the mineral content of wood is probably high enough to bind volatile sulphur compounds.

Optimisation and validation of the final digestion procedure were performed using the biological certified reference materials NIST 1572 Citrus Leaves, RM 8436 Durum Wheat Flour, NIST 1547 Peach Leaves, BCR 101 Spruce Needles, NIST 1573 Tomato Leaves, RM 8436 Durum Wheat Flour NIST 1515 Apple Leaves and NIST 1575 Pine Needles. Table 1 presents the averaged results of triple determinations in comparison to the certified values and concentration ranges found in the literature $[1,6,9,23-$ 29]. A comparison to the specific literature values as well as information on used digestion method, required sample amounts and analysis methods can be found in Table S2 in the online available supplementary information. The wavelengths used are specified in the last column of the table. Detection limits were determined with six procedural blanks according the 3-Sigma plus Blank method. All values are given in $\mathrm{mg} \mathrm{L}^{-1}$ for direct determination of the solutions and in $\mu \mathrm{g} \mathrm{g}^{-1}$ calculated for the solid samples. Most of the results matched the range of the certified values \pm uncertainties and showed recovery rates of $95 \%$ to $105 \%$. Only elements close to the detection limits such as for $\mathrm{Cu}$ or $\mathrm{Cr}$ showed higher recovery rates. Reproducibility for higher element contents ranges between $0.5 \%$ and $5 \%$, whereas for concentrations close to trace level the standard deviation is higher.

However, the sulphur content of commercially available certified reference materials is relatively high with 1,200 to $6,000 \mu \mathrm{g} \mathrm{g}^{-1}$ in contrast to about $20-200 \mu \mathrm{g} \mathrm{g}^{-1}$ sulphur in real wood samples. Higher contents are usually found in bark. Therefore, self-prepared spiked cellulose and wood powder samples were used for the validation of the lower concentration range. Spiked cellulose as well as spiked wood standards of a final concentrations of 4, 20, 50, 100 and $200 \mu \mathrm{g} \mathrm{g}^{-1}$ sulphur were prepared as follows: Portions of $2 \mathrm{~g}$ cellulose powder or $2 \mathrm{~g}$ wood powder were doped with different amounts of a $200 \mu \mathrm{g} \mathrm{L}^{-1}$ sulphur solution (1:5 dilution of a $1,000 \mu \mathrm{g} \mathrm{mL}{ }^{-1}$ Alfa Aesar Sulphur ICP standard) and well mixed in pre-cleaned PTFE vials by additionally adding of $6 \mathrm{ml}$ ultrapure water to obtain a homogeneous paste. The paste was dried at $80^{\circ} \mathrm{C}$ until weight constancy. The dried spike self-prepared standards were then pulverised in an agate mortar. The samples were digested using the procedure described above. Figure 1 represents the sulphur recovery rates for the double determinations of the spiked cellulose and the spiked wood powder standards. The suitability of the microwave 
Table 1 Averaged results of triple determinations for plant certified reference materials in comparison to certified values and literature results

\begin{tabular}{|c|c|c|c|c|c|c|c|c|c|c|c|c|c|c|c|c|c|}
\hline \multirow{2}{*}{$\begin{array}{l}\text { Certified Reference } \\
\text { Material } \\
\text { Sample ID }\end{array}$} & \multicolumn{3}{|c|}{ BCR 101 Spruce Needles } & \multicolumn{4}{|c|}{ NIST 1575 Pine Needles } & \multicolumn{6}{|c|}{ RM 8436 Durum Wheat Flour } & \multicolumn{4}{|c|}{ NIST 1573 Tomato Leaves } \\
\hline & $\begin{array}{l}\text { Found } \\
{[\mu \mathrm{g} / \mathrm{g}]}\end{array}$ & $\begin{array}{l}\text { Certified/ } \\
\text { (non-certified) } \\
\text { values }[\mu \mathrm{g} / \mathrm{g}]\end{array}$ & $\begin{array}{l}\text { Min-Max } \\
\text { Literature }\end{array}$ & $\begin{array}{l}\text { Found } \\
{[\mu \mathrm{g} / \mathrm{g}]}\end{array}$ & \multicolumn{2}{|c|}{$\begin{array}{l}\text { Certified/ } \\
\text { (non-certified) } \\
\text { values }[\mu \mathrm{g} / \mathrm{g}]\end{array}$} & $\begin{array}{l}\text { Min-Max } \\
\text { Literature }\end{array}$ & \multicolumn{2}{|c|}{$\begin{array}{l}\text { Found } \\
{[\mu \mathrm{g} / \mathrm{g}]}\end{array}$} & \multicolumn{2}{|c|}{$\begin{array}{l}\text { Certified/ } \\
\text { (non-certified) } \\
\text { values }[\mu \mathrm{g} / \mathrm{g}]\end{array}$} & \multicolumn{2}{|c|}{$\begin{array}{l}\text { Min-Max } \\
\text { Literature }\end{array}$} & $\begin{array}{l}\text { Found } \\
{[\mu \mathrm{g} / \mathrm{g}]}\end{array}$ & \multicolumn{2}{|c|}{$\begin{array}{l}\text { Certified/ } \\
\text { (non-certified) } \\
\text { values }[\mu \mathrm{g} / \mathrm{g}]\end{array}$} & $\begin{array}{l}\text { Min-Max } \\
\text { Literature }\end{array}$ \\
\hline $\mathrm{Al}$ & $156 \pm 3$ & $173 \pm 5$ & $126-165$ & $516 \pm 14$ & & $15 \pm 30$ & 520.0 & $19.6=$ & \pm 2.8 & 11.7 & \pm 4.7 & 11 & & $727 \pm 37$ & $(12$ & 200) & $1130-1250$ \\
\hline $\mathrm{Ca}$ & $4506 \pm 98$ & $4280 \pm 80$ & $4150-4150$ & $4111 \pm 78$ & 410 & $0 \pm 200$ & $3950-4300$ & $293 \pm$ & & 278 & \pm 26 & 278 & & $29385 \pm 23$ & & $000 \pm 3000$ & $29100-33000$ \\
\hline $\mathrm{Cr}$ & $2.9 \pm 0.1$ & $(2.7)$ & 2 & $1.2 \pm 0.34$ & & $6 \pm 0.2$ & $1.9-2.8$ & $<\mathrm{DL}$ & & 0.023 & \pm 0.009 & & .02 & $2.2 \pm 0.3$ & & \pm 0.5 & $3.4-5.6$ \\
\hline $\mathrm{Cu}$ & $3.2 \pm 0.5$ & (5) & nd & $1.9 \pm 0.02$ & & $3 \pm 0.3$ & $2.9-3.4$ & $2.9 \pm($ & & 4.3 & \pm 0.69 & 4 & .3 & $5.3 \pm 0.2$ & $11 \pm$ & & $10.6-11.4$ \\
\hline $\mathrm{Fe}$ & $157 \pm 0.7$ & $(151)$ & 149 & $181 \pm 5.7$ & & $0 \pm 10$ & $185-208$ & $42 \pm 1$ & & 41.5 & & 41 & & $626 \pm 28$ & 690 & $0 \pm 25$ & $600-807$ \\
\hline K & $6293 \pm 7.5$ & $(6000)$ & $6123-6123$ & $3657 \pm 129$ & 370 & $0 \pm 200$ & $2980-3900$ & 3127 & \pm 15 & 3180 & \pm 140 & 3180 & & $43938 \pm 39$ & $96 \quad 446$ & $600 \pm 300$ & $44400-49200$ \\
\hline $\mathrm{Mg}$ & $533 \pm 0.5$ & $619 \pm 9$ & 564 & $1073 \pm 36$ & & & $1180-1410$ & 1010 & & 1070 & \pm 80 & 1070 & & $6826 \pm 37$ & $7 \quad(70$ & 00) & $6600-7150$ \\
\hline $\mathrm{Mn}$ & $936 \pm 1.9$ & $915 \pm 11$ & $867-930$ & $664 \pm 23$ & & $75 \pm 15$ & $634-660$ & $15.5=$ & \pm 0.3 & 16 & \pm 1 & 16 & & $221 \pm 0.8$ & 238 & $8 \pm 7$ & $225-233$ \\
\hline $\mathrm{Na}$ & $23.6 \pm 1.9$ & & 44 & $12.1 \pm 0.56$ & & & 36 & $9.1 \pm$ & & & \pm 6.1 & 16 & & $151 \pm 5$ & & & $480-601$ \\
\hline $\mathrm{P}$ & $1745 \pm 0.1$ & $1690 \pm 40$ & nd & $1179 \pm 41$ & 120 & $0 \pm 200$ & $827-1210$ & 2712 & \pm 0.5 & 2900 & \pm 220 & 2900 & & $3457 \pm 22$ & 340 & $00 \pm 200$ & 3350 \\
\hline $\mathrm{S}$ & $1688 \pm 5$ & $1700 \pm 40$ & 1647 & $1101 \pm 47$ & & & $900-1250$ & 1656 & & 1930 & \pm 280 & 1930 & & $6030 \pm 10$ & & & 6100 \\
\hline $\mathrm{Zn}$ & $39 \pm 1$ & $35.3 \pm 2.3$ & 31 & $78 \pm 4.6$ & & & $63-82$ & $27.2=$ & \pm 1.1 & 22.2 & \pm 1.7 & 22 & & $60 \pm 0.2$ & $62 \pm$ & & $59.3-73$ \\
\hline $\begin{array}{l}\text { Certified Reference } \\
\text { Material }\end{array}$ & \multicolumn{3}{|c|}{ NIST 1572 Citrus Leaves } & \multicolumn{4}{|c|}{ NIST 1547 Peach Leaves } & & \multicolumn{6}{|c|}{ NIST 1515 Apple Leaves } & & & \\
\hline Sample ID & $\begin{array}{l}\text { Found } \\
{[\mu \mathrm{g} / \mathrm{g}]}\end{array}$ & $\begin{array}{l}\text { Certified/ } \\
\text { (non-certified) } \\
\text { values }[\mu \mathrm{g} / \mathrm{g}]\end{array}$ & $\begin{array}{l}\text { Min-Max } \\
\text { Literature }\end{array}$ & $\begin{array}{l}\text { Found } \\
{[\mu \mathrm{g} / \mathrm{g}]}\end{array}$ & & $\begin{array}{l}\text { Certified/ } \\
\text { (non-certified } \\
\text { values }[\mu \mathrm{g} / \mathrm{g}]\end{array}$ & $\begin{array}{ll}\text { Min-Max } \\
\text { ed) Literature } \\
\text { g] }\end{array}$ & & $\begin{array}{l}\text { Founc } \\
{[\mu \mathrm{g} / \mathrm{g}}\end{array}$ & & $\begin{array}{l}\text { Certified } \\
\text { (non-cer } \\
\text { values [ }\end{array}$ & $\begin{array}{l}\mathrm{d} / \\
\mathrm{ftified}) \\
\mu \mathrm{g} / \mathrm{g}]\end{array}$ & & $\begin{array}{l}- \text { Max } \\
\text { rature }\end{array}$ & $\begin{array}{l}\mathrm{DL} \\
{[\mu \mathrm{g} / \mathrm{g}]}\end{array}$ & Used wave & elength \\
\hline $\mathrm{Al}$ & $92 \pm 0.1$ & $92 \pm 15$ & $86-100.5$ & $263 \pm 0$ & & $249 \pm 8$ & $224-329$ & & $293 \pm$ & & $286 \pm 9$ & & 330 & & 3.7 & Al 308.215 & 5, Al 396.152 \\
\hline $\mathrm{Ca}$ & $31407 \pm 185$ & $31500 \pm 1000$ & $28100-32000$ & $0 \begin{array}{ll}15955 \pm 7\end{array}$ & & $15600 \pm 200$ & $15656-1$ & 5840 & 15480 & $0 \pm 178$ & $15260 \pm$ & 150 & 1440 & $00-15341$ & 21 & Ca 396.84 & 7, Ca 422.673 \\
\hline $\mathrm{Cr}$ & $0.99 \pm 0.02$ & $(0.8)$ & $0.7-0.84$ & $1.5 \pm 0$ & & (1) & $0.6-1.32$ & & $<\mathrm{DL}$ & & $(0.3)$ & & 0.33 & -1 & 0.75 & Cr 267.716 & \\
\hline $\mathrm{Cu}$ & $14.3 \pm 0.3$ & $16.5 \pm 1$ & $14.7-17.2$ & $2.98 \pm 0$ & .06 & $3.7 \pm 0.4$ & $3.5-4.7$ & & $3.42=$ & \pm 0.04 & $5.64 \pm 0$. & & $5.7-$ & -6.2 & 0.9 & $\mathrm{Cu} 327.39$ & \\
\hline $\mathrm{Fe}$ & $85 \pm 1.9$ & $90 \pm 10$ & $80-92$ & $218 \pm 2$ & & $218 \pm 14$ & $193-238$ & & $77.5=$ & \pm 0.5 & $83 \pm 5$ & & $72-c$ & & 1.1 & Fe 238.204 & $4, \mathrm{Fe} 259.940$ \\
\hline $\mathrm{K}$ & $18200 \pm 3$ & $18200 \pm 600$ & $14100-18744$ & $44 \quad 25000 \pm 1$ & & $24300 \pm 300$ & $23000-2$ & 4402 & 1636 & $2 \pm 37$ & $16100 \pm$ & 200 & 1580 & $00-16000$ & 15 & K 766.491, & K 769.897 \\
\hline $\mathrm{Mg}$ & $5800 \pm 11$ & $5800 \pm 300$ & $5550-5757$ & $7 \quad 4459 \pm 2$ & & $4320 \pm 80$ & $4051-41$ & & 2756 & \pm 9.8 & $2710 \pm 8$ & & 2378 & $8-2460$ & 0.6 & Mg 279.55 & $53, \mathrm{Mg} 280.270$ \\
\hline $\mathrm{Mn}$ & $22.4 \pm 0.2$ & $23 \pm 2$ & $19.7-22.4$ & $98.2 \pm 0$ & & & $82.9-95$. & & $49 \pm 0$ & & $54 \pm 3$ & & $51-5$ & & 0.8 & Mn 257.61 & 10, Mn 259.372 \\
\hline $\mathrm{Na}$ & $177 \pm 0.1$ & $160 \pm 20$ & $160-171.4$ & $20.8 \pm 1$ & & $24 \pm 2$ & nd & & $15.9=$ & \pm 0.2 & $24.4 \pm 1$ & & nd & & 2.0 & $\mathrm{Na} 589.592$ & \\
\hline $\mathrm{P}$ & $1367 \pm 0.9$ & $1130 \pm 200$ & $1330-2000$ & $1461 \pm 1$ & & $1370 \pm 70$ & $1265-12$ & & 1649 & & $1590 \pm 1$ & & 1435 & & 15 & P 213.618, & , P 214.914 \\
\hline $\mathrm{S}$ & $3940 \pm 27$ & $(4070)$ & $3030-4300$ & $1568 \pm 2$ & & $(2000)$ & $1544-20$ & & 1744 & \pm 19 & $(1800)$ & & 1745 & $5-1767$ & 8 & S 180.669, & , S 181.972 \\
\hline $\mathrm{Zn}$ & $34 \pm 0.1$ & $29 \pm 2$ & $23.5-30.7$ & $25 \pm 1$ & & $(17.9)$ & $17.1-19$ & & $13.7 \pm$ & \pm 0.2 & $12.5 \pm 0$ & & $11-1$ & & 1.9 & Zn 202.548 & \\
\hline
\end{tabular}




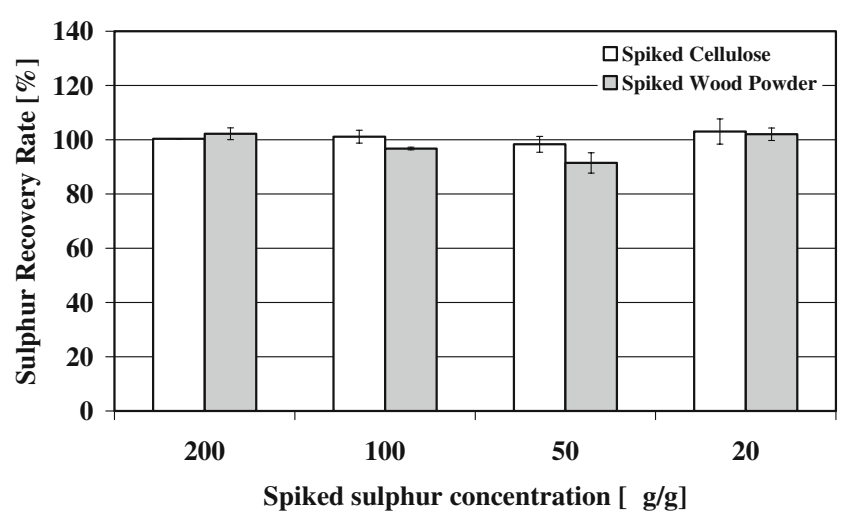

Fig. 1 The sulphur recovery rates for the double determinations of the spiked cellulose and the spiked wood powder standards

procedure developed for this work is clearly shown. The spiked cellulose standards gave recovery rates between $98.3 \%$ and $103 \%$ and the wood standards showed variations in a range of $91.5 \%$ to $102.2 \%$.

\section{Signal enhancement by USN}

Ultrasonic nebulizer USN was used to improve the signal intensity for low concentrated elements such as sulphur and phosphorus. Figure S2 in the online available supplementary information shows the USN intensity enhancement for the USN compared to a conventional Meinhard nebulizer for sulphur and phosphorus at selected wavelengths. The signal enhancement factor of the USN in comparison to the Meinhard nebulizer was about 7 for sulphur and about 13 for phosphorus, which corresponds to the findings of Wennrich et al. [9] who found enhancement factors of 4.9 for sulphur and 4.3 for phosphorus with a Spectroflame ICP-OES (Spectro Analytical Instruments, www.spectro. com). Also the other elements showed a ten to 500 times higher signal when USN was used.

Trees as environmental archives

Investigation of sulphur in tree rings is of particular interest, since $\mathrm{S}$ is both a pollutant (mainly in form of anthropogenic $\mathrm{SO}_{2}$ ) and occurring naturally (e.g. as $\mathrm{SO}_{4}{ }^{2-}$ in soil). Sulphur is one of the essential macronutrients for plants, and as such plays an important role for physiological processes such as photosynthesis, dissimilation and also for defence via the production of antioxidants like glutathione $[30,31]$.

Three uptake mechanisms for atmospheric $\mathrm{SO}_{2}$ have to be taken into account: 1 . via needles (leaves), 2. via roots after deposition, 3. via run-off water through the bark. Uptake as sulphate in the rhizosphere is the main mechanism of sulphur acquisition by plants. However, in heavily polluted areas, $\mathrm{SO}_{2}$ can become an additional sulphur source. The trace gas enters the needles of conifers via the stomata, is removed from the substomatal cavity by solubilisation in the aqueous phase of the apoplastic space, and is taken up into the cytoplasm of surrounding cells [32]. Once inside the cell, either storage in the vacuole or assimilation into the amino acid cysteine takes place by the sulphate assimilation pathway [33, 34]. Allocation of sulphur from source needles to the main stem is low [35]. Instead, most of the accumulated sulphur is allocated to the following needle generation [36]. Falling needles, enriched in sulphur, can contribute to raising the soil sulphur content. Wet deposition of sulphur remains the most important sulphur source of forests. Due to the huge canopy surface of a Norway spruce tree, important amounts of aerosols and fog are scavenged. Crown interception is three times higher in Norway spruce than for a deciduous tree like beech (Fagus sylvatica) [37]. As a consequence, the sulphur accumulation in the soil under Norway spruce is four times higher than under beech. This is accentuated by the fact that perennial foliage leads to uninterrupted crown interception during winter, when airborne sulphur from heating reaches a maximum. Accordingly, Norway spruce accumulates two times more sulphur in its phytomass than beech.

An accumulation of anthropogenic sulphur in conifers at an industrial site was proposed by Gaoming [14]. The high sulphur content measured in Chinese pine (Pinus tabulaeformis) are believed to reflect the important industrial $\mathrm{SO}_{2}$ emissions in Chengde, northern China. While in industrialised countries such as Switzerland, desulphurisation of crude oil and reduced use of coal permitted to cut $\mathrm{SO}_{2}$ emissions by a factor of 3 after they peaked around the eighties of the last century, but the global emission rate still increases. Developing countries such as China depend on coal-fired power plants for covering their increasing energy needs. High sulphur content of coal then leads to an enormous $\mathrm{SO}_{2}$ release. In the latest report of the International Panel on Climate Change (IPCC [50]), scenarios of a worldwide increase in $\mathrm{SO}_{2}$ emissions were predicted.

In the present article, mineral content profiles of Norway spruce trees will be discussed, with a special focus on sulphur. Beside sulphur, especially the profiles of macronutrients potassium and calcium, as well as of the micronutrient manganese were obtained. The results will be discussed with special regard to anthropogenic influences and plant physiological processes.

\section{Sulphur}

The principal focus of this study was to assess whether $\mathrm{SO}_{2}$ emissions can be reconstructed using tree drill cores sampled at different sites. Due to the uptake mechanisms mentioned above (uptake via roots, needles, and bark), 
Norway spruce was predestined for this purpose. The species is widespread in Switzerland and found at sites with completely different immission profiles, such as the Alps and the Swiss Plateau.

The emissions rates of $\mathrm{SO}_{2}$ in Switzerland were particularly pronounced towards the end of the seventies and at the beginning of the eighties. Measures taken to reduce these emissions led to a sustained decrease of $\mathrm{SO}_{2}$ pollution. The wood sulphur content was determined in trees from three distinct locations in Switzerland: Düdingen (countryside, near to a motorway), Frieswil (countryside) and St Moritz (Alpine) (see profiles Fig. 2). In Fig. 2a, the averaged total $\mathrm{S}$ content profile achieved for the time range 1954-2003 for three trees from Frieswil (F2, F3, F6) are displayed. The average standard deviation of the pooled data amounts to $13 \%$. Such deviations have to be taken into account, since the sampled trees all are individuals, grown

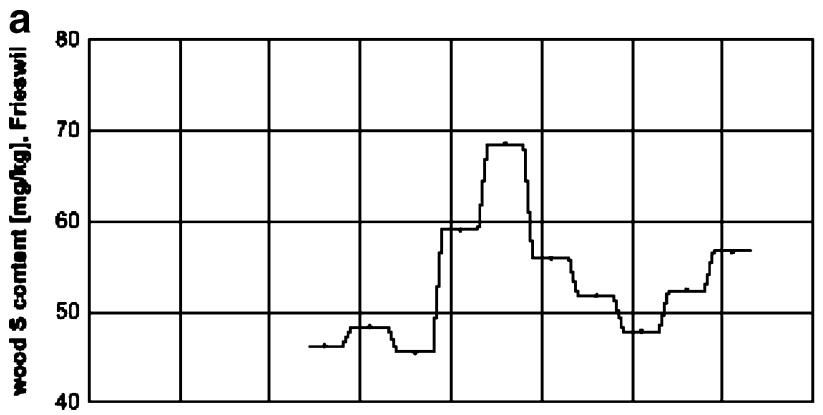

b

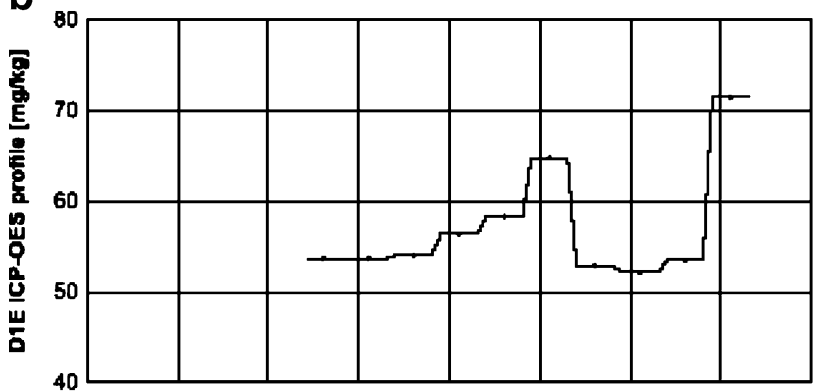

C

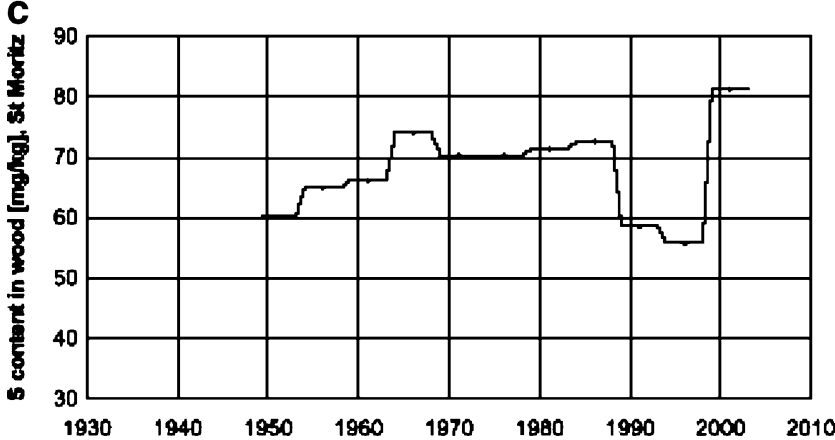

Fig. 2 a-c Pooled total sulphur content profiles (1934-2003) for three Norway spruce tree in Frieswil (a), a Norway spruce tree in Düdingen (b) and two Norway spruce trees in St. Moritz (c) under natural conditions. Fig. $2 \mathrm{~b}$ displays the total sulphur content profiles (1934-2003) for a Norway spruce tree in Düdingen. Although the Düdingen trees have an average cambial age of $96 \pm 4$ years and the trees from Frieswil an average cambial age of $142 \pm 6$ years, the profiles look very similar. There is only a slight variation in the Swiss Plateau sulphur profiles for the first three quarters of the $20^{\text {th }}$ century, whereas in the forth quarter, i.e. the tree rings corresponding to 1974-1984, a clear sulphur peak is visible. This corresponds to the period when $\mathrm{SO}_{2}$ emissions reached their maximum in Switzerland, as also evaluated by the Federal Office for the Environment (FOEN) and the NABEL National Air Pollution Monitoring Network [38, 39]. Düdingen and Frieswil are both rural sites, separated by $20 \mathrm{~km}$ distance only. Both sites reflect the immission situation of their respective region, which is why there is a slight shift between both peaks. The Düdingen sampling site at $580 \mathrm{~m}$ above sea level is close to a direct emission source. The motorway A12 (Berne-Fribourg), which is next to the sampled Düdingen forest, acts as a local sulphur dioxide source, which was detected also in the peat bog nearby [21] and also by measurements of trees. Although there is no direct pollution source in Frieswil $(740 \mathrm{~m}$ above sea level.), deposition of anthropogenic sulphur occurs as well in trees from this site and is likely to be the reason for the peak.

Trees from the alpine forest show that the sampling site of St Moritz (Engadine) is more secluded from the bulk of the $\mathrm{SO}_{2}$ emissions in Switzerland. Since little local sources are present there, the sampling site is only affected by low long distance transport of sulphur. Sulphur profiles obtained from St Moritz trees do not display the characteristic maximum at 1974-1984 found in trees and peat bogs from the Swiss Plateau, which corresponds to the immission maximum in this time. Furthermore the tree profiles resemble sulphur content obtained from the St Moritz peat bog [40], which also has no maximum peak at this time. Moreover, the total sulphur content shows a generally higher S content as seen in Fig. 2c. The reason is probably not anthropogenic origin, but rather due to the particularities of the Alpine environment which lead to a very slow growth rate of the trees.

However, sulphur profiles in trees as well as in peat bogs correspond to the local immission situations of the different sampling sites. Also measurements performed by EMPA for the National Air Pollution Monitoring Network (NABEL, http://www.empa.ch/nabel; http://www.bafu.admin.ch/luft) showed that annual average $\mathrm{SO}_{2}$ concentrations in the Alps (e.g. NABEL sampling site Davos) are up to ten times lower than on the Swiss Plateau (e.g. NABEL measurement sites Härkingen or Payerne).

In most recent years, i.e. close to the cambium where cell division occurs, maximum sulphur content was 
observed in all measured trees, including the alpine trees (Fig. 2). This effect is natural and not due to anthropogenic $\mathrm{SO}_{2}$ emissions, which continue to decrease steadily in Switzerland. The reasons of this rapid decrease by a factor of 1.5 in direction of the pith are protein decay during heartwood formation and recycling of sulphate. Apparently, sulphur recycling is not complete during this process, and wood is used for sulphur storage [22, 41]. Thus, in case of higher sulphur input, as on the Swiss Plateau in the years 1970-1980, the amount of sulphur remaining in the wood tissue increases. The trend line displays a clear upward trend of the wood sulphur content towards the second half of the century. Part of it is due to the naturally higher sulphur content near the cambium (five most recent years), but the principal reason is likely the $\mathrm{SO}_{2}$ emissions of the Swiss Plateau. The upward trend in alpine trees (Fig. 2c) is much less pronounced, and principally due to the proximity of the cambium.

While in trees from the Swiss Plateau, the sapwoodheartwood transition zone was found around 1,970 \pm 6 years in average, in St Moritz trees, the average boundary ranged in the tree rings at $1,941 \pm 16$ years. Thus, the period with maximum $\mathrm{SO}_{2}$ emissions (1970-1980) is situated in the sapwood in both cases. The pollution peak which is visible in two types of archives from the Swiss plateau (Düdingen trees and peat bog, Frieswil trees) is likely not affected by water transportation and element translocation, since the conducting system is most efficient in the outermost tree rings of Norway spruce [42].

Two trees from the Frieswil forest showed deviating sulphur profiles, presented as F1 (A) and F4 (B) in Fig. 3, Reasons for the different pattern of these tree profiles were investigated further. It is known that fungal infection can alter the cation content of heartwood [43]. It appears that the sulphur content can be massively altered, too: In tree $\mathrm{F} 1$, the two huge $\mathrm{S}$ peaks found in wood segments corresponding to 1934-1938, and 1949-1953 are connected with decayed tree rings. Microscopy of small slices of these two infected spots prior to acid digestion revealed the presence of a fungal pathogen, presumably Ophiostoma piceae or Ceratocystis piceae (Engesser, personal communication). Further investigations are needed to estimate whether the huge increase is due to an accumulation of sulphur by the pathogen, or to a defence mechanism established by the tree.

In contrast, tree $\mathrm{F} 4$ shows very low $\mathrm{S}$ contents related to a compression wood zone ranging from about 1940-1980. This type of reaction wood is found exclusively in conifers and built on the stressed side of the tree in case of mechanical pressure e.g. cause by wind, snow, slope or proximity of another tree. It distinguishes itself by its wider, denser and darker growth rings. Compression wood contains up to $25 \%$ less cellulose than normal wood [44] and

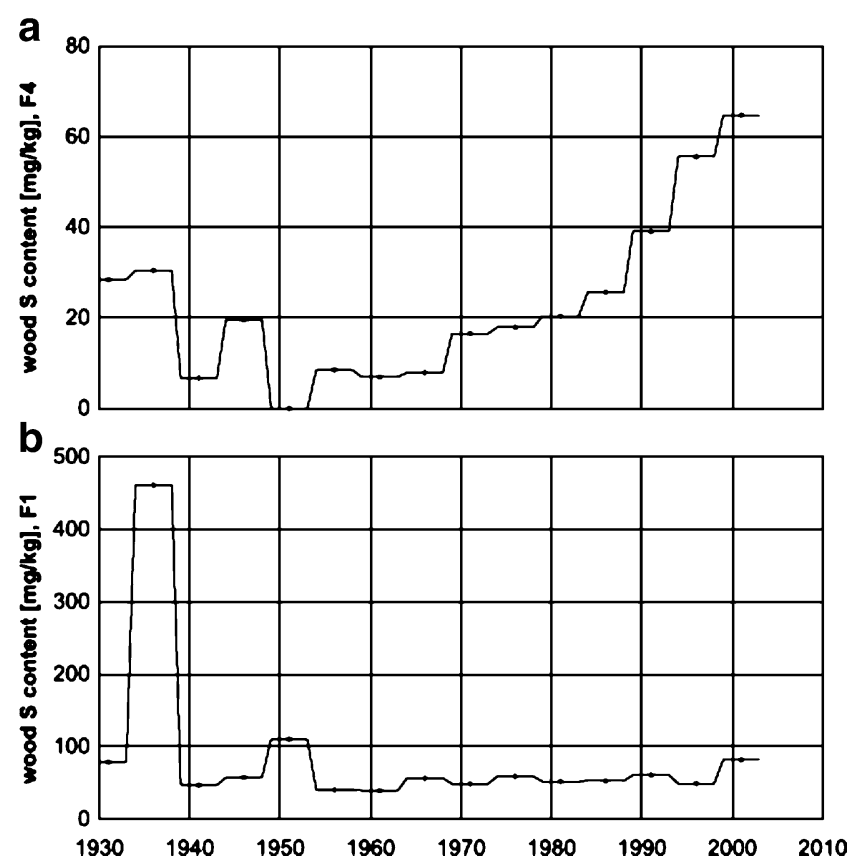

Fig. 3 Effect of fungal decay (b) and compression wood (a) on the sulphur profile in two different Norway spruce trees in Frieswil

the augmented lignin content provides more hydroxyl binding sites, which leads to higher cation content compared to the wood on the opposite side of the tree [45]. Thus, the variations of the total $\mathrm{S}$ content shown in Fig. 3 are of physiological origin and presumably independent from the sapwood-heartwood transition zone as well. Manganese content was altered. too. Consequently, the trees F1 and F4 were not included in the calculations presented in the Fig. 2.

Bark is exposed to precipitation and run-off water, and thus constantly enriched with minerals retrieved from the run-off water [45]. In the bark, nutrients can transiently be stored in parenchyma cells or/and can be subjected to longdistance transport in the phloem (living tissue carrying organic nutrients and which lies underneath the bark). Substances poisonous for the tree can be exuded, e.g. as resin. Therefore, the element content of the bark is usually much higher than in wood tissue. The presence of sulphur in water running along the stem may lead to higher sulphate content of the bark, too [46]. Additionally, the phloem plays an important role for the cycling of sulphur in trees and contains sulphate and organic sulphur such as glutathione as well. Both sulphate and organic sulphur can be enhanced when sulphur availability is high [47]. For these reasons, the average bark sulphur content of seven trees from the three locations of the present study ( $423 \mu \mathrm{g} \mathrm{g}^{-1} \pm 42 \%$ ) is about eight times higher than the average wood sulphur content $\left(54 \mu \mathrm{g} \mathrm{g}^{-1} \pm 14 \%\right)$. 


\section{Potassium, calcium and manganese}

A detailed discussion on selected nutrients can be found in the online available supplementary information. Profiles of the macronutrients potassium (Figure S3) and calcium (Figure S4) as well as the micronutrient manganese (Figure S5) are presented and discussed.

\section{Conclusion}

Trees are challenging archives and the interpretation is complex, since anthropogenic and natural physiological signals can be intertwined. Pollutants, changes in soil chemistry and climate not only influence tree growth but also have an impact on xylem chemistry. Thus, for a correct interpretation of element content profiles, knowledge about tree physiology is mandatory. Physiological factors of the tree such as heartwood formation, responses to pathogens and reaction wood formation can be identified from the chemical content of tree rings and must therefore be taken into consideration.

Norway spruce wood is a suitable archive for sulphur dioxide. As shown in the present article as well as in a further publication [17], the requirements postulated by Walkenhorst and Hagemeyer for retrospective bioindication in trees $[48,49]$ are met in the case of sulphur:

(1) a constant relationship between element supply and accumulation

(2) storage in tree rings constricted to a short time period

(3) storage in a limited, known number of tree rings

(4) no retroactive remobilisation of element

(5) identical radial distribution in different spots of the stem

(6) identical radial distribution in the stems of different trees of the same sampling site.

Additionally, we show that further influencing factors have to be taken into account when using Norway spruce as an environmental archive:

(1) The signal provided by the outermost ten-12 tree rings cannot be interpreted for the archive, since sap transport is very active in this zone.

(2) The transition zone from sapwood to heartwood must be determined directly after sampling.

(3) Wood density and tree ring width profiles must be obtained for recognition of growth changes (sudden growth of a tree liberated from competition may alter its chemical profile drastically).

(4) In tree rings near the cambium, high sulphur and potassium contents, and low calcium and manganese contents are natural.
In trees exempt of pathogens and reaction wood, $\mathrm{S}, \mathrm{K}, \mathrm{Ca}$ and $\mathrm{Mn}$ show quite uniform patterns that allow general physiological interpretation of the profiles for Norway spruce, and, in the case of $\mathrm{S}$, to monitor past pollution events.

Acknowledgements The authors like to thank F. H. Schweingruber, D. Nievergelt, J. Esper, W. H. Schoch, R. Engesser, and S. Zimmermann at WSL for providing advice and assistance for radiodensitometry. We also thank $\mathrm{C}$. Zwicky from the Empa Laboratory for Solid State Chemistry and Catalysis, A. Wichser and O. Nagel from the Empa Laboratory for Analytical Chemistray, and Raoul Seitzinger from the University of Berne for performing several digestions for the plant standard reference materials. Moreover, we are grateful to Max Haldimann from BAG who provided several certified plant reference materials for comparison. Last but not least we are grateful to A. Niederer from Empa Graphic Section, who drawn several element profiles.

\section{References}

1. Ward NI, Savage JM (1994) Metal dispersion and transportational activities using food crops as biomonitors. Sci Total Environ 147:309-319

2. Hafez AA, Goyal SS, Rains DW (1991) Quantitative-determination of total sulfur in plant-tissues using acid digestion and ionchromatography. Agron J 83:148-153

3. Randall PJ, Spencer K (1980) Sulfur-content of plant-material-a comparison of methods of oxidation prior to determination. Commun Soil Sci Plant Anal 11:257-266

4. Ivanova J, Korhammer S, Djingova R, Heidenreich H, Markert B (2001) Determination of lanthanoids and some heavy and toxic elements in plant certified reference materials by inductively coupled plasma mass spectrometry. Spectrochim Acta Part B At Spectrosc 56:3-12

5. Dolgopolova A, Weiss DJ, Seltmann R, Stanley C, Coles B, Cheburkin AK (2004) Closed-vessel microwave digestion technique for lichens and leaves prior to determination of trace elements $(\mathrm{Pb}, \mathrm{Zn}, \mathrm{Cu})$ and stable $\mathrm{Pb}$ isotope ratios. Int $\mathrm{J}$ Environ Anal Chem 84:889-899

6. Levine KE, Ross GT, Fernando RA, Blake JC, Sparacino CM (2004) Trace element content of senna study material and selected sennabased dietary supplements as determined by inductively coupled plasma-optical emission spectrometry and inductively coupled plasma-mass spectrometry. Commun Soil Sci Plant Anal 35:835-851

7. Poykio R, Peramaki P, Niemela M (2005) The use of Scots pine (Pinus sylvestris L.) bark as a bioindicator for environmental pollution monitoring along two industrial gradients in the KemiTornio area, northern Finland. Int J Environ Anal Chem 85:127-139

8. Wieberneit N (2001) Einsatz der ICP-Massenspektrometrie zur Multielementbestimmung in biologischen Proben. Ph.D. thesis, University of Hamburg

9. Wennrich R, Mroczek A, Dittrich K, Werner G (1995) Determination of nonmetals using ICP-AES-techniques. Fresenius J Anal Chem 352:461-469

10. Zhao F, Mcgrath SP, Crosland AR (1994) Comparison of 3 wet digestion methods for the determination of plant sulfur by inductively-coupled plasma-atomic emission-spectroscopy (ICPAES). Commun Soil Sci Plant Anal 25:407-418

11. Matusiewicz H, Barnes RM (1985) Tree-ring wood analysis after hydrogen-peroxide pressure decomposition with inductively cou- 
pled plasma atomic emission-spectrometry and electrothermal vaporization. Anal Chem 57:406-411

12. Queirolo F, Valenta $\mathrm{P}$ (1987) Trace determination of $\mathrm{Cd}, \mathrm{Cu}, \mathrm{Pb}$ and $\mathrm{Zn}$ in annual growth rings by differential pulse anodicstripping voltammetry. Fresenius Z Anal Chem 328:93-98

13. Padilla KL Anderson KA (2002) Trace element concentration in tree-rings biomonitoring centuries of environmental change. Chemosphere 49:575-585

14. Gaoming J (1996) Tree analysis for determination of pollution history of Chengde City, North China. J Environ Sci 8:77-85

15. Din-51577 (2001) Testing of mineral oils and fuels

16. Din-51724 (1999) Testing of solid fuels - determination of the sulphur content

17. Barrelet T, Ulrich A, Rennenberg H, Zwicky CN, Krähenbühl U (2008) Assessing the suitability of Norway spruce wood as an environmental archive for sulphur. Environ Pollut (in press) doi:10.1016/j.envpol.2008.05.004

18. Struis RPWJ, Ludwig C, Barrelet T, Krähenbühl U, Rennenberg H (2008) Studying sulfur functional groups in Norway spruce year rings using $\mathrm{S}$ L-edge total electron yield spectroscopy. Sci Total Environ 403(1-3):196-206 (15 September 2008)

19. Schweingruber FH (1990) Radiodensitometry. In: Cook ER, Kairukstis LA (eds) Methods of dendrochronology, applications in environmental sciences. Kluwer Academic, Dordrecht, pp 5563

20. Din 51577-5 (2001) Testing of mineral oils and fuels-determination of the chlorine and bromine content-part 5: direct determination by optical emission spectral analysis with inductively coupled plasma (ICP OES)

21. Jeker P, Krähenbühl U (2001) Sulfur profiles of the twentieth century in peat bogs of the Swiss midlands measured by ICP-OES and by IC. Chimia 55:1029-1032

22. Ulrich A, Barrelet T, Krähenbühl U (2007) Spatially resolved plant physiological analysis using LA-HR-ICP-MS. Chimia 61:111-111

23. Ihnat M, Dabeka RW, Wolynetz MS (1994) Preparation and homogeneity characterization of 10 agricultural food reference materials for elemental composition. Fresenius J Anal Chem 348:445-451

24. Markert B, Reus U, Herpin U (1994) The application of TXRF in instrumental multielement analysis of plants, demonstrated with species of moss. Sci Total Environ 152:213-220

25. Jonah SA, Williams IS (2000) Nutrient elements of commercial tea from Nigeria by an instrumental neutron activation analysis technique. Sci Total Environ 258:205-208

26. Poykio R, Torvela H, Peramaki P, Kuokkanen T, Ronkkomaki H (2000) Comparison of dissolution methods for multi-element analysis of some plant materials used as bioindicator of sulphur and heavy metal deposition determined by ICP-AES and ICP-MS. Analusis 28:850-854

27. Poykio R, Peramaki P (2003) Acid dissolution methods for heavy metals determination in pine needles. Environ Chem Lett 1:191-195

28. Stephens WE, Calder A (2004) Analysis of non-organic elements in plant foliage using polarised X-ray fluorescence spectrometry. Analytica Chimica Acta 527:89-96

29. Yamashita CI, Saiki M, Vasconcellos MBA, Sertie JAA (2005) Characterization of trace elements in Casearia medicinal plant by neutron activation analysis. Appl Radiat Isotopes 63:841-846

30. Foyer C, Rennenberg H (2000) Regulation of glutathione synthesis and its role in abiotic and biotic stress defense. In: Brunold C, Rennenberg H, De Kok LJ, Stulen I, Davidian JC (eds) Sulfur nutrition and sulfur assimilation in higher plants: molecular, biochemical and physiological aspects. Paul Hauptpp, Bern, pp 127-153
31. Schurmann P (1993) Plant thioredoxins. In: De Kok LJ, Stulen I, Rennenberg $\mathrm{H}$, Brunold Ch, Rauser W (eds) Sulfur nutrition and sulfur assimilation in higher plants. SPB Acad, The Hague, pp 153-162

32. Rennenberg H, Polle H (1994) Metabolic consequences of atmospheric sulphur influx into plants. In: Wellburn A, Alscher $\mathrm{R}$ (eds) Plant responses to the gaseous environment. Chapman and Hall, London, pp 165-180

33. Noji M, Saito M, Aono M, Saji H, Saito K (2000) Modulation of cysteine biosynthesis and resistance to $\mathrm{SO} 2$ in transgenic tobacco overexpressing cysteine synthase in cytosol and chloroplasts. In: Brunold C, Rennenberg H, De Kok LJ, Stulen I, Davidian JC (eds) Sulfur nutrition and sulfur assimilation in higher plants: molecular, biochemical and physiological aspects. Paul Haupt, Bern, pp 289-290

34. Rennenberg H (1984) The fate of excess sulfur in higher-plants. Annu Rev Plant Physiol Plant Mol Biol 35:121-153

35. Schupp R, Schatten T, Willenbrink J, Rennenberg H (1992) Longdistance transport of reduced sulfur in spruce (Picea-abies L). J Exp Bot 43:1243-1250

36. Schneider A, Schatten T, Rennenberg H (1994) Exchange between phloem and xylem during long-distance transport of glutathione in spruce trees (Picea-abies [Karst] L). J Exp Bot 45:457-462

37. Ulrich B, Mayer R, Khanna PK (1979) Loading of chemicalelements in precipitation at the solling. Z Pflanzenernahr Bodenkd 142:601-615

38. EMPA (2000). Technical report of the national air pollution monitoring network (NABEL), www.empa.ch.

39. Buwal/Safel (1995) Vom Menschen verursachte Luftschadstoffemissinen in der Schweiz von 1900 bis 2010, BUWAL Schriftenreihe Umwelt, 256

40. Schreier R (2005) Studies on past climatic and environmental changes by chemical investigations of peat cores from Upper Engadine (Swiss alpine area). Ph.D. thesis, University of Bern.

41. Barrelet T, Ulrich A, Rennenberg H, Krähenbühl U (2006) Seasonal profiles of sulphur, phosphorus, and potassium in Norway spruce wood. Plant Biol 8:462-469

42. Cutter BE, Guyette RP (1993) Anatomical, chemical, and ecological factors affecting tree species choice in dendrochemistry studies. J Environ Qual 22:611-619

43. Ostrofsky A, Jellison J, Smith KT, Shortle WC (1997) Changes in cation concentrations in red spruce wood decayed by brown rot and white rot fungi. Can J For Res 27:567-571

44. Timell T (1986) Compression wood in gymnosperms, Vol. 1, 2 , and 3.. Springer, Berlin and New York

45. Witte KM, Wanty RB, Ridley WI (2004) Engelmann spruce (Picea engelmannii) as a biological monitor of changes in soil metal loading related to past mining activity. Appl Geochem 19: 1367-1376

46. Kauneliene V, Mosback H, Ceburnis D, Spokauskiene D (1999) Use of bark of Scots pine for bio-monitoring of airborne pollutant deposition. Environ Chem Phys 21:43-50

47. Herschbach C, Van Der Zalm E, Schneider A, Jouanin L, De Kok LJ, Rennenberg H (2000) Regulation of sulfur nutrition in wildtype and transgenic poplar over-expressing gamma-glutamylcysteine synthetase in the cytosol as affected by atmospheric H2S. Plant Physiol 124:461-473

48. Walkenhorst A, Hagemeyer J (1997) Distribution of Cd, Pb, and $\mathrm{Zn}$ in above ground parts of a 55-year-old spruce tree (Picea abies [L.] Karst.). J Appl Bot 71:164-167

49. Hagemeyer J, Lohrie K (1995) Distribution of $\mathrm{Cd}$ and $\mathrm{Zn}$ in annual xylem rings of young spruce trees [Picea-Abies (L) Karst] grown in contaminated soil. Trees 9:195-199

50. Intergovernmental Panal on Climate Change (IPCC) (2007) Climate change 2007, 4th IPCC Assessment Report, http://www. ipcc.ch/ 